\title{
Mathematics teachers' reflective practice within the context of adapted lesson study
}

\author{
Author: \\ Barbara Posthuma ${ }^{1}$ \\ Affiliation: \\ ${ }^{1}$ Faculty of Education \\ Sciences, North-West \\ University, South Africa \\ Correspondence to: \\ Barbara Posthuma

\section{Email:} \\ barbara.posthuma@gmail. \\ com

\section{Postal address:} \\ Private Bag X1290, \\ Potchefstroom 2520, \\ South Africa

\section{Dates:} \\ Received: 17 Nov. 2011 \\ Accepted: 21 Oct. 2012 \\ Published: 19 Nov. 2012 \\ How to cite this article: \\ Posthuma, A.B. (2012). \\ Mathematics teachers' \\ reflective practice within the \\ context of adapted lesson \\ study. Pythagoras, 33(3), Art. \\ \#140, 9 pages. http://dx.doi. \\ org/10.4102/pythagoras. \\ v33i3.140
}

(C) 2012. The Authors. Licensee: AOSIS OpenJournals. This work is licensed under the Creative Commons Attribution License.
There seems to be paucity of research in South Africa on mathematics teachers' reflective practice. In order to study this phenomenon, the context of lesson study (in an adapted form) was introduced to five mathematics teachers in a rural school in the Free State. The purpose was to investigate their reflective practice whilst they collaboratively planned mathematics lessons and reflected on the teaching of the lessons. Data were obtained through interviews, video-recorded lesson observations, field notes taken during the lesson study group meetings and document analyses (lesson plans and reflective writings). The adapted lesson study context provided a safe space for teachers to reflect on their teaching and they reported an increase in self-knowledge and finding new ways of teaching mathematics to learners. This finding has some potential value for planning professional learning programmes in which teachers are encouraged to talk about their classroom experiences, share their joys and challenges with one another and strive to build a community of reflective practitioners to enhance their learners' understanding of mathematics.

\section{Introduction}

The ability to reflect on practice is considered a necessity for effective instruction (Sowder, 2007). When teachers reflect on their classroom practice they carefully consider the problems in their own teaching and think about how those problems are related to their learners' understanding of concepts. They are aware of the consequences of their teaching and how their own assumptions or beliefs can influence their teaching.

However, Day (1999) argues that other teachers are needed in the reflective process in order to achieve deep levels of reflection. It seems that systematic investigation of practice with the help of a critical colleague enhances the reflective process. Teachers may for instance find it beneficial to come together in groups or teams to discuss their teaching in a supportive atmosphere (Farrell, 2004). This view mirrors Pollard's (2002) finding that the value of engaging in reflective activity is almost always enhanced if carried out in association with other colleagues. York-Barr, Sommers, Ghere and Montie (2006) concur with Pollard and maintain that reflecting on practice with another person has the potential to greatly enrich understanding and support improvements in practice. They believe that reflecting with a colleague can assist in gaining awareness of some of the fixed assumptions a teacher might have and as such help the teacher to view events from another perspective (York-Barr et al., 2006).

Lesson study is a professional development model that provides an opportunity for teachers to reflect collaboratively on their planning and teaching of a lesson. Murata (2011, p. 10), for instance, claims that lesson study is centred around teachers' interests, is learner focused, provides opportunities for teachers to be researchers, provides plenty of time and opportunities for teachers to reflect on their teaching practice and learner learning, and is collaborative.

\section{Problem statement}

In spite of what has been said in the introduction, there seems to be paucity of research in South Africa on mathematics teachers' reflective practice, which strengthened the rationale to research this issue. Furthermore, lesson study has not been used widely as a professional development model in South Africa, despite evidence that the lesson study structure enables teachers to engage in significant professional development with a minimum of resources and offer possibilities for rural teachers to use the resources they already have to improve the teaching and learning of mathematics (Taylor, Anderson, Meyer, Wagner \& West, 2005).

Based on evidence regarding the importance of teachers reflecting collaboratively on their teaching, lesson study (in an adapted form) was used as the context of an investigation of the nature of mathematics teachers' reflective practice (Posthuma, 2011). This article reports on how 
the adapted lesson study context influenced mathematics teachers' reflections before, during and after teaching a lesson.

The article is structured as follows. Firstly, a conceptual theoretical framework is outlined. This is followed by an exposition of the research method that was applied. The findings are listed thereafter, followed by a discussion against the backdrop of the conceptual theoretical framework. The article concludes with suggestions for further research.

\section{Conceptual theoretical framework}

The main concepts that this research addressed were mathematics teachers' reflective practice and lesson study (in an adapted form). In this section these concepts are linked theoretically to establish a conceptual theoretical framework for the study that was done. Two theories, symbolic interaction and social reconstructionism, informed the conceptualisation of the study.

\section{Symbolic interaction theory}

Symbolic interaction theory examines the ways in which people make sense of their life situations and the ways in which they go about their activities, in conjunction with others, on a day-to-day basis (Prus, 1996). As a theoretical framework, it suited the interpretive nature of this study which is centrally concerned with meanings teachers construct whilst reflecting collaboratively on their planning and teaching of a lesson. The four basic propositions of symbolic interaction are:

- individuals act and interact within larger networks of individuals and groups that have an impact on them

- human beings are active in shaping their own behaviour

- individuals can engage in thought and change their behaviour as they interact with others

- and to understand human conduct requires a study of their covert behaviour (Blumer, 1969).

This final proposition has major methodological implications, namely that the procedures used should allow sympathetic introspection as a part of the methodology (Pedro, 2001).

The adapted lesson study context was explored not only against the backdrop of symbolic interaction, but also within the milieu of the social reconstructionist theory, discussed in the following section.

\section{Social reconstructionist theory}

Zeichner and Tabachnick (1991) outlined four major theoretical traditions in the reflective teaching literature. Each of these is concerned with thoughts and practices connected to particular educational aims and values. These traditions are the academic, social efficiency, developmentalist and social reconstructionist traditions. The latter views schools and teachers as agencies of change for the creation of a more just and humane society. This tradition has three central strands. The first encourages teachers to focus their attention both inwardly at their own practice and outwardly at the social conditions wherein these practices are situated (Carr \& Kemmis, 1986). The second advocates a democratic and emancipatory force as teachers focus their reflections on issues related to inequality and injustice, in the context of their own classroom, school and society. The third demonstrates a commitment to reflection as a communal activity and seeks to create communities of learning where teachers can support and sustain one another (Zeichner \& Tabachnik, 1991, p. 9).

According to Mewborn (1999), 'reflection and action together are seen as a bridge across the chasm between educational theory and practice' (p. 317). Lesson study formed the practice part of this study where the teachers tried to construct meaning about their classroom practice socially through their interaction with one another. In the adapted lesson study process the teachers were constantly reflecting on their practice and both theories (theory of symbolic interactionism and social constructionist theory) embrace the social interaction and reflection concepts.

\section{Mathematics teachers' reflective practice}

Thoughts on reflection and reflective practice have evolved over many decades, if not centuries, through carefully constructed theory and research applications (York-Barr et al., 2006). Dewey is frequently recognised as the eminent 20th-century influence on reflection in education (Ottesen, 2007; Pollard, 2002; Rodgers, 2002; York-Barr et al., 2006; Zeichner \& Liston, 1996). For Dewey (1933), true reflective practice takes place only when the individual is faced with a real problem that they need to resolve and seek to resolve in a rational manner.

The seminal work of Schön (1983) has also inspired a renewed interest in reflective practice in the field of education (Lee \& Tan, 2004; Valli, 1997). Although Schön clearly relates reflection to action through using the terms 'reflection-inaction' and 'reflection-on-action', other researchers seem to view reflection as a special form of thought (Artzt, ArmourThomas \& Curcio, 2008; Sparks-Langer \& Colton, 1991). For the purpose of this investigation, reflection was considered to involve questioning the effectiveness of practice before (reflection-for-practice), during (reflection-in-practice) and after the act of teaching (reflection-on-practice).

Research indicates that the content of teachers' reflection in their classrooms relates to their learners' prior knowledge (Ward \& McCotter, 2004), their own instructional strategies (Lee, 2005; Ward \& McCotter, 2004), discipline (Lee, 2005), the teacher-learner relationship (Lee, 2005), mathematical content (McKeny, 2006) and disturbing aspects of teaching experiences (Ottesen, 2007).

The quality of teachers' reflection can be measured at different levels as identified by a number of researchers (e.g. Lee, 2005; Valli, 1992; Van Manen, 1977). For the purpose of this study the teachers' quality of reflection was rated according to Lee's (2005) levels of reflection. According to Lee, a teacher who 
reflects on Level 1 (R1: 'Recall level') is mainly concerned with mastery and/or application of technical means for achieving given educational ends, and includes a simple description of observation or a focus on behaviours or skills from past experience. Reflection on Level 2 (R2: 'Rationalisation level') is directed at an interpretive understanding of the meanings of educational experiences and choices of action within a particular social and institutional context (Lee, 2005). Reflection on Level 3 (R3: 'Reflective level') links classroom practice to the broader arena of political, moral and ethical forces (Lee, 2005) and this type of reflection is considered to be critical reflection (Jay \& Johnson, 2002).

In order to reflect on a critical level about the teaching and learning of mathematics, the teacher has to question moral, ethical, and other types of normative criteria related directly and indirectly to the classroom (Van Manen, 1977). Within the social reconstructionist tradition, teaching and teacher education are important determinants for the creation of a more just and humane society. This perspective prioritises critical reflection in terms of how teachers' actions influence the stability within both the school and society (ZwodiakMyers, 2009).

\section{Lesson study}

Lesson study is a collaboration-based teacher professional development approach that originated in Japan (Fernandez \& Yoshida, 2004). According to Takahashi, Watanabe and Yoshida (2006), lesson study has played an important role in professional development in Japan since the public education system was introduced more than a hundred years ago. One reason for the popularity of lesson study in Japan might be that:

lesson study provides Japanese teachers with opportunities to make sense of educational ideas within their practices; change their perspectives on teaching and learning; learn to see their practices from a learner's perspective; and enjoy collaborative support among colleagues. (Takahashi, Watanabe \& Yoshida, 2006, p. 201)

The lesson study process is cyclical and has the following basic stages (Murata, 2011, p. 6):

1. Consider goals for student learning and development, plan a research lesson based on these goals.

2. Observe the research lesson and collect data on student learning and development.

3. Use these data to reflect on the lesson and on instruction more broadly.

4. If desired, revise and re-teach the research lesson to a new group of students.

Research has shown that lesson study impacts on teachers' understanding of learner thinking, it enhances teachers' content knowledge and awareness of new approaches to teaching, it helps teachers to connect their practices to school goals and broader goals, and it creates a demand for improved instruction and allows competing views to be heard during the reflection-stage of the lesson study cycle (Lewis, 2000). Friedman (2005) argues that the habit of personally reflecting on one's teaching that occurs during the lesson study process is a habit that remains with teachers long after the lesson study process is over.

\section{Research on lesson study and mathematics teaching}

Meyer and Wilkerson (2011) investigated the impact of lesson study on teachers' knowledge for teaching mathematics and found that lesson study provided opportunities for improved teacher knowledge in three of the five groups that participated. They conclude that more research is needed to examine the impact of lesson study on teachers' knowledge.

Olson, White and Sparrow (2011) studied the influence of lesson study on mathematics teachers' pedagogy and found that three of the five teachers who completed the lesson study process changed their pedagogies over 18 months. Before lesson study, the three teachers maintained control of the classroom discourse and frequently asked 'why?' without knowing what to do with the information that they gained. After completing the lesson study process, these three teachers asked purposeful questions and used the learners' responses to guide instructional decisions.

\section{Lesson study in the South African context}

In South Africa, a school-based in-service education intervention programme, modelled along the lines of the Japanese lesson study, was launched in 2000 in Mpumalanga (Jita, Maree \& Ndlalane, 2006). According to Jita et al. (2006), the lesson study approach has established a system in which teachers have grown accustomed to relying on one another, coaching, leading discussions and exploring alternative solutions to problems experienced in their teaching of mathematics.

A study by Coe, Carl and Frick (2010), in a rural primary school in the Western Cape, sought to determine the value that a group of teachers placed on the process of lesson study as a model for their own learning and instructional improvement. Their findings highlight the following benefits of lesson study:

1. Lesson study offers an effective strategy to bring teachers out of isolation, allowing them to experience meaningful collaboration with fellow teachers.

2. The process of lesson study is embedded within the classroom context by setting goals and then planning instruction with the purpose of moving the learners closer to the goals. A connection between the content of the research lesson and the remainder of the curriculum is established. Furthermore, lesson study provides an opportunity to observe the learners during the research lesson. The post-lesson discussion is also valuable in terms of validating and developing the perceptions of learners in relation to the prescribed goal.

3. Lesson study can be a catalyst for transforming new instructional strategies into routine classroom practice.

4. Continuous support (by fellow teachers) is embedded within the model of lesson study. 
The lesson study process involves reflection on the planning and teaching of a lesson as a communal activity, and hence fits into the framework of the social reconstructionist tradition. Teacher reflection within the lesson study model of professional development focuses on social conditions of practice (a group of teachers trying to make sense of the teaching and learning of mathematics) in a democratic way.

The conceptual theoretical framework (discussed previously) links mathematics teaching to teachers' reflective practice, within the context of adapted lesson study. The lesson study cycles of planning, teaching and evaluation correspond with teachers' reflection-for-practice, reflection-in-practice and reflection-on-practice. The theory of symbolic interaction and the social reconstructionist tradition both embrace critical reflection and social interaction and therefore together form the backdrop of this study.

\section{Empirical investigation Research design}

A case study design suitable for a qualitative approach was chosen. According to Cohen, Manion and Morrison (2005) a case study provides a unique example of real people in real situations. Case studies offer a multi-perspective analysis in which the researcher considers not just the voice and perspective of one or two participants in a situation, but also the views of other relevant groups and the interaction between them (Nieuwenhuis, 2010).

\section{Participants}

The participants in this study were five mathematics teachers from one school in the Thabo Mofutsanyana district in the Free State. The criteria for selection included the factors of convenience, access and willingness to participate. Meetings with the teachers took place in the teachers' school environment.
The biographical information of the participants is provided in Table 1. Pseudonyms are used to protect the identities of the participants.

Table 1 indicates that all the participants were experienced teachers with basic teaching qualifications and, except for Dianne, had all been teaching for 14 years or longer. The pass rate for mathematics at the rural township school was 19\% in 2010. The medium of instruction at the school was English. Setati, Adler, Reed and Bapoo (2002) argue that in the remote rural areas of South Africa where access to English outside the classroom is severely limited, the classroom context is more appropriately described as a learning environment in which English is a foreign language. This notion has implications for the present study, where the participants had to reflect on their practice through the medium of English. In addition, they all taught mathematics to learners who did not have textbooks.

\section{Procedure}

The data-gathering procedure followed is outlined in Table 2.

Although the group provided feedback on how to improve each of the lesson plans, the final lesson plan for each teaching phase remained the responsibility of the teacher who would teach the lesson. This is a deviation from the Japanese lesson study, although the same procedure was followed as suggested by Lewis (2000):

the research lesson should be observed by other teachers; the research lesson should be planned collaboratively; there should be an overarching goal for the research lesson; and the research lesson should be recorded and discussed. (pp. 4-6)

The lesson study cycle is illustrated in Figure 1.

\section{Data collection}

The lesson study cycle involves three phases:

- planning

- teaching

- evaluation (reflection).

TABLE 1: Biographical information of participants.

\begin{tabular}{|c|c|c|c|c|c|}
\hline Category & Dianne & Mary & Morgan & Sipho & Vicky \\
\hline Age & 32 & 44 & 39 & 48 & 44 \\
\hline Highest qualification & ACE & FDE & BSc Ed & FDE & BEd Hons \\
\hline Teaching experience (years) & 8 & 19 & 14 & 22 & 17 \\
\hline Grades teaching & $11,12 \mathrm{ML}$ & 8 & 10,12 & 8,9 & $9,10,11$ \\
\hline Home language & Sesotho & Sesotho & Sesotho & Sesotho & Sesotho \\
\hline
\end{tabular}

Source: Posthuma, A.B. (2011). The nature of mathematics teachers' reflective practice. Unpublished doctoral dissertation. University of Pretoria, Pretoria, South Africa. Available from http://upetd. up.ac.za/thesis/available/etd-04252012-164207/

ACE, Advanced Certificate in Education; FDE, Further Diploma in Education; ML, Mathematical Literacy.

TABLE 2: Procedure for data gathering.

\begin{tabular}{ll}
\hline Lesson study cycle & Description of cycle \\
\hline Planning phase & $\begin{array}{l}\text { The participants in the lesson study group cooperatively planned an initial lesson for Grade } 8 \text { on solving linear equations. The lesson } \\
\text { study goal was to improve learners' understanding of related mathematics concepts. }\end{array}$ \\
\hline Teaching phase & $\begin{array}{l}\text { During the teaching phase of the first lesson study cycle the planned lesson was taught by the Grade } 8 \text { teacher (Mary). This lesson was } \\
\text { observed by the researcher together with an assistant who managed the video recorder. The same procedure was followed during the } \\
\text { next four lesson study cycles. }\end{array}$ \\
Reflection (evaluation) phase & $\begin{array}{l}\text { During the feedback (evaluation/reflection) phase of each lesson study cycle the participants of the lesson study group viewed the } \\
\text { video-recorded lesson the same afternoon in a post-conference. (This is another deviation from the original Japanese lesson study } \\
\text { model, where the lesson study group observes the lesson whilst it is taught.) The focus was not only on the teacher's presentation but } \\
\text { also on the learners' understanding of the concepts that were taught. A consensus was reached on whether the lesson study goal was } \\
\text { achieved. During each of these sessions the group suggested improvements to the lesson plan for the next teaching cycle. }\end{array}$ \\
\hline
\end{tabular}




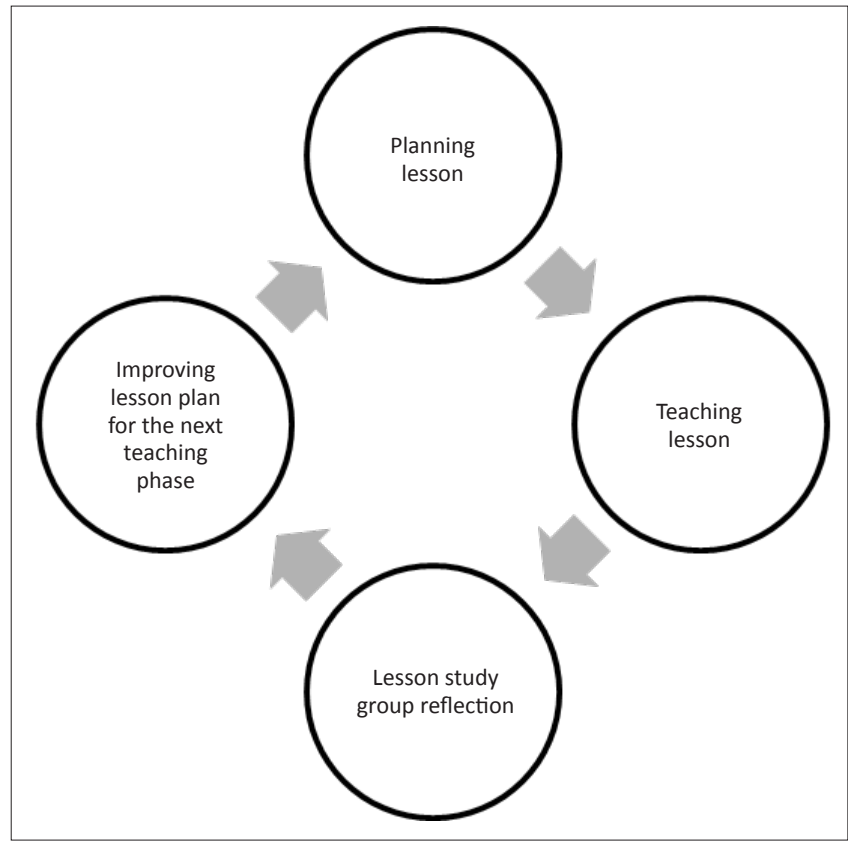

FIGURE 1: Lesson study cycle.

Data were collected to coincide with each of these phases. During the planning phase, data were collected through document analyses (lesson plans); during the teaching phase, data were collected through lesson observation (video recorded so that the lesson study group could observe the lesson the same afternoon); during the reflection or evaluation phase, data were collected through semistructured interviews, reflective writings and field notes. A final group interview with all the participants was conducted after the last lesson study cycle to establish how the reflective processes of lesson study influenced their classroom practice.

\section{Data analysis}

The data gathered during the lesson study cycles were analysed during and after the data-gathering process, in line with Creswell's (2003, p. 18) qualitative case study approach in which the researcher collects open-ended, emerging data with the primary intent of developing themes from the data. All interviews were transcribed verbatim and the computer software program Atlas.ti 6 (ATLAS.ti Scientific Software Development, 2010) was used to assist with the data management, coding, categorisation, abstracting and conceptualising stages of the analysis.

\section{Trustworthiness}

The qualitative data collected were in the form of observations, interviews and document analyses. The observations and interviews were electronically recorded and transcribed. Participants had the opportunity to review these transcriptions at the end of the data collection period to ensure accuracy and provide additional research data. Data from multiple sources were used to help verify findings: data collected through interviews were verified, for instance, with information gathered from the observations and the document analyses.

\section{Ethical considerations}

Permission to access a school in the Thabo Mofutsanyana district was obtained from the Free State Education Department. Potential participants were verbally briefed and presented with details of the research in writing. Each teacher signed a letter of consent. Participation was voluntary and the teachers had the option to withdraw at any stage. They were assured that all data would be kept confidential and pseudonyms would be used in the report. In addition, the principles of respect for personal autonomy, benevolence and justice guided the research.

\section{Findings}

\section{Findings from the analyses of the lesson plans}

The first lesson was planned collaboratively by the group (the 'research lesson') and subsequent lesson plans were refined by the lesson study group and presented by the different teachers. The participants used a lesson plan template that made provision for reflection on their learners' current understanding of the concepts. The template also made provision for reflection after the lesson was taught. The lesson plans were analysed to establish whether the teachers reflected on their learners' thinking and understanding of the concepts to be taught, whether provision was made for learners who might have struggled with the concepts or learners who needed to be challenged, and whether there was any evidence of linking the current lesson to the lesson study goal determined by the lesson study group.

The analysis of the lesson plans revealed no reflection on learners' current mathematical knowledge or on how to address any misconceptions that might have occurred when teaching the concepts. There was also no evidence in these lesson plans of teaching mathematical concepts with a longterm goal in mind. For example, during the post-observation interview Mary admitted that she had not planned the lesson with her learners in mind: 'you know, I did not now think of them ... grasping gradually ...' and Dianne said: '... previously we did not spend much time on lesson plans.' In addition, the level of the content the participants selected to teach differed. For example, the content that the lesson study group selected for Mary's Grade 8 class (the first lesson plan) was on a very low cognitive level (the examples used were $x+3=7, x-10=3$ and $32+x=34)$ in contrast to the content that Morgan selected for his Grade 10 class (which was arranged from basic examples to more complicated examples, including fractional algebraic equations such as $\left.\frac{10 y+1}{2}=\frac{4(7 y+1)}{5}\right)$. The selection of tasks on a low cognitive level might reveal the individual teacher's perception of their learners' ability to cope with the mathematics content.

\section{Findings of lesson study group reflection after observing lessons}

The lesson study group observed the video recording of each lesson and discussed their observations. According to Taylor et al. (2005), observing a lesson enables teachers to 
shift their thinking from a teaching focus to a learning focus whilst puzzling over their learners' mathematical thinking. As observers, they are free to focus on the actual work the learners are doing, as well as the learners' thought processes.

During the lesson observations the focus was on the teacher's presentation as well as on the learners' content knowledge. Mary's learners struggled to transpose the constant term to the other side of the equation (using the additive inverse) and as a result the volume of work done during the 45-minute period was very low. It seemed to me that Mary did not understand her learners' thinking and failed to encourage them to clearly explain and justify their reasoning. For example, she asked one learner to come to the board to solve the linear equation $32+x=34$. The learner struggled and Mary did not help her, but instead told her to ask learners from the class to help, which resulted in chaos. She moved between the desks to mark the learners' work and if a learner wrote a wrong answer, she sent the learner to the board to look at the examples, not helping the learner to understand the method or asking them to explain their solution method to her. According to Warfield, Wood and Lehman (2005) such teachers do not reflect deeply about their learners' mathematics or about their own teaching.

However, Morgan allowed learners to solve the equations using their own methods and expected them to explain and justify their reasoning and to listen to and question the reasoning of other learners. In this way he actively involved all learners in the lesson:

I invite the learners to come and show me what they are doing on the board, so that I can exactly know what they know and what they don't know ...

The lesson study group reflected critically on Mary's lesson and expressed concern about treating the learners fairly and catering for all learners' needs (reflecting on Lee's R3: Reflective level). During the group reflection, Morgan said:

We should cater for all learners ... sometimes you plan a worksheet for your class, and after one or two examples you see they don't understand, and then only a few sums are done ...

The lesson study group seemed to reflect more openly and talk more freely as the lesson study process continued. They constantly reflected on their learners' lack of understanding of basic concepts, for example, learners struggling to add $3 x$ to $6 x$.
Table 3 summarises the content of reflection, as well as the level of the group reflections on each lesson.

From Table 3, it appears that the participants reflected on their teaching styles, on their learners' understanding of concepts, and on matters such as class size, textbooks, class arrangement and language. Within the framework of the symbolic interaction theory, the teachers were making sense of their own and each other's classroom practice collaboratively. During the group reflections on the lessons they observed, the lesson study group reflected critically (R3) on Mary and Vicky's lessons, considering the implications of each teacher's actions on their learners' understanding of mathematics. The video recordings revealed Mary's impatience with the learners' inability to solve basic linear equations as well as Vicky's impatience with her learners' lack of basic mathematical knowledge (such as the product of multiplying two negative numbers will be a positive number) and Vicky admitted: 'Ai, ... I lose my temper sometimes ... (laughs).' Morgan replied: 'We need to be very patient with the learners. When we teach them, we need to make sure you motivate them.' Against the backdrop of the social reconstructionist theory, the teachers who participated in this study reflected communally, supported each other during the feedback sessions, but also critically considered the effects of their own and their colleagues' classroom practice on their learners' mathematical growth and well-being.

\section{Findings of final group reflection on the influence of lesson study on teaching mathematics}

All the participants reported that they had gained personally and professionally from being part of the lesson study group. A summary of their reflections appears in Figure 2.

The benefits of lesson study reported by the participants are summarised in Figure 2, a circular diagram that illustrates the influence of the lesson study cycle on the participants' reflective journeys. They reported that they had improved their lesson planning as a result of the lesson study group planning sessions. They were more confident about their teaching after seeing themselves on video. They expressed a deeper awareness of their learners' needs. They learned from watching their fellow participants on video to change their teaching to become more learner-centred, and they felt as if

TABLE 3: Summary of content and level of reflection during the lesson study group reflections.

\begin{tabular}{|c|c|c|c|c|c|}
\hline $\begin{array}{l}\text { Lesson study group } \\
\text { reflections }\end{array}$ & $\begin{array}{l}\text { Mary's lesson on } \\
24 \text { February } 2011\end{array}$ & $\begin{array}{l}\text { Morgan's lesson on } \\
04 \text { March } 2012\end{array}$ & $\begin{array}{l}\text { Vicky's lesson on } \\
10 \text { March } 2011\end{array}$ & $\begin{array}{l}\text { Sipho's lesson on } \\
05 \text { May } 2012\end{array}$ & $\begin{array}{l}\text { Dianne's lesson on } \\
05 \text { May } 2012\end{array}$ \\
\hline Content of reflection & $\begin{array}{l}\text { The introduction; her } \\
\text { teaching style; learners' } \\
\text { understanding; class size } \\
\text { and lack of textbooks; } \\
\text { her lesson plan }\end{array}$ & $\begin{array}{l}\text { Teaching of the content; } \\
\text { teaching style (learner- } \\
\text { centred); lesson plan }\end{array}$ & $\begin{array}{l}\text { Her methodology; } \\
\text { learners' understanding } \\
\text { of concepts; her } \\
\text { expectations of her } \\
\text { learners; teaching style; } \\
\text { class arrangement and } \\
\text { management; learners' } \\
\text { needs }\end{array}$ & $\begin{array}{l}\text { His introduction; his } \\
\text { teaching style; learners' } \\
\text { understanding of } \\
\text { concepts }\end{array}$ & $\begin{array}{l}\text { Her teaching style; the topic; } \\
\text { language }\end{array}$ \\
\hline
\end{tabular}

Source: Posthuma, A.B. (2011). The nature of mathematics teachers' reflective practice. Unpublished doctoral dissertation. University of Pretoria, Pretoria, South Africa. Available from http:// upetd.up.ac.za/thesis/available/etd-04252012-164207/ 


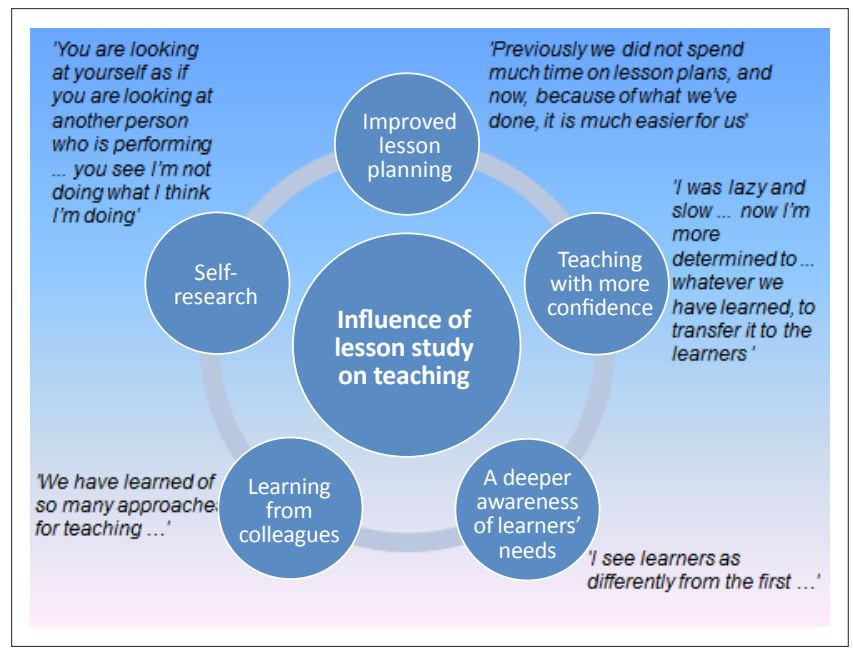

Source: Posthuma, A.B. (2011). The nature of mathematics teachers' reflective practice Unpublished doctoral dissertation. University of Pretoria, Pretoria, South Africa. Available from http://upetd.up.ac.za/thesis/available/etd-04252012-164207/

FIGURE 2: Influence of lesson study on teaching as reported by the participants.

they were doing self-research by being part of this research study. Against the framework of the symbolic interaction theory, these teachers reflected collaboratively and tried to make sense of their classroom practice and their teaching of mathematics. They reported positively on the lesson study process, but whether they will adapt their classroom behaviour as revealed by the lesson observations remains to be researched.

\section{Discussion}

Lesson study as reported by this research supports Lewis's (2000) view that lessons planned in the lesson study context impact on teachers' individual professional development and their view of learners (they 'learn to see children'). New content and approaches are acquired, competing views of teaching emerge and a demand for improvement is created. It also confirms Hix's (2008) contention that the sum of planning collaboratively, anticipating learner responses, creating evaluation questions for observers, observing the public teaching, and discussing and reflecting on the observations are beneficial to teachers' reflective practice. The results of this study mirror Friedman's (2005) report that the major advantage of lesson study for teachers is the collaboration factor. Taylor et al. (2005) report on the following benefits of the lesson study professional development model:

- an effective detailed lesson plan achieves the goal of more effective learning by learners

- the lesson study model provides a highly motivated structure for planning and teaching a lesson

- reflecting and thinking in the company of other teachers allow for sharing, interacting questioning assumptions, and reassessing common practices

- observing a lesson enables a shift in thinking from a teaching focus to a learning focus

- focusing on learner thinking provides opportunities for feedback to support changes in teaching mathematics

- lesson study transforms working relationships and conversations between teachers.
As expected in terms of the symbolic interaction theory, the adapted lesson study provided a context for the teachers to derive meaning about their teaching actions through social interaction with their fellow teachers. However, they were also actively shaping their own behaviour and reflecting on how to change their teaching actions to improve their learners' understanding of mathematics concepts. In line with the social reconstructionist tradition, which prioritises reflection-in-practice and -on-practice, the teacher becomes an agent of change to improve social conditions of practice as a result of critical reflection. This issue is especially applicable in South African society, where most teachers teach in rural areas, using a language that is not their mother tongue, in schools with limited resources.

\section{Limitations of the study}

The five participants were of the same cultural and language group, and taught at the same school. A more diverse sample that excludes ethnic and geographical biases could arguably have cast more light on the research problem.

Another limitation of this research study pertains to the researcher's inability to speak the home language of the participants. Language emerged as a contextual factor that possibly influences participants' reflective practice (Posthuma, 2011). Although allowance was made for an interpreter during the last group reflection, the participants' verbal and written reflections showed that they struggled to express themselves in English during the lesson study group meetings. One has to allow for the fact that their reflections might have been misinterpreted.

\section{Further research}

It would be worthwhile to undertake a follow-up study with the participants of this study to understand the longterm effects of reflective processes in a lesson study context. Furthermore, there might be other contextual factors that influence mathematics teachers' reflective practice that need to be researched further, for example, gender, personality characteristics and culture. The reason gender is considered to be a possible influence on the reflective process is because the male participants in this study were very reluctant to write about their reflections in a reflective diary. Personality characteristics might also play a role in teachers' reflective practice, based on Dewey's (1933) three attitudes that he considered to be integral to reflection, namely, openmindedness, responsibility and wholeheartedness. Reflection might also be culturally bound. For example, Lee and Tan (2004) investigated student teachers' reflective practice in Malaysia and found that their private reflections were on a deeper level than their public reflections. An intercultural study, for example, comparing South African mathematics teachers' reflective practice to that of a different culture, will provide for a more comprehensive body of knowledge on reflective practice.

The results of this study could furthermore be used in the planning of future continuing professional teacher 
development programmes. The positive feedback of the participants on the lesson study process suggests that lesson study should be initiated in other settings. Further research should explore lesson study as a model in South Africa for successful continuing professional teacher development and teacher education programmes.

\section{Conclusion}

The teachers who participated in this study were teaching mathematics to learners in a rural area with few or no resources, in a language that was not their mother tongue. The symbolic interaction theory provided a backdrop for the adapted lesson study as a way for these mathematics teachers to derive meaning about their teaching actions through social interaction with their fellow teachers. The adapted lesson study experience allowed them an escape from their isolated practices, providing them an opportunity to reflect on their problems cooperatively in a safe space. However, they were also actively shaping their own behaviour and some were critically reflecting on how to change their teaching actions to improve their learners' understanding of mathematics concepts. The social reconstructionist approach prioritises reflection-in-practice and reflection-on-practice that enables the teacher to become an agent of change to improve social conditions of practice. This issue is especially applicable in South African society where teachers' histories need to be taken into account when planning and implementing professional development programmes.

\section{Acknowledgements}

I would like to acknowledge the support of my supervisor, Prof. Kobus Maree and co-supervisor, Dr Gerrit Stols in the completion of this research. In addition, I thank Prof. Hannes van der Walt from North-West University as well as SANPAD (South Africa Netherlands Research Programme on Alternatives in Development) for supporting me in writing this article.

\section{Competing interests}

I declare that I have no financial or personal relationship(s) which may have inappropriately influenced the writing of this article.

\section{References}

Artzt, A.F., Armour-Thomas, E., \& Curcio, F.R. (2008). Becoming a reflective mathematics teacher. New York, NY: Lawrence Erlbaum Associates.

ATLAS.ti Scientific Software Development GmbH. (2010). ATLAS.ti 6 Qualitative Data Analysis Software. Berlin: ATLAS.ti Scientific Software Development GmbH. Available from http://www.atlasti.com

Blumer, H. (1969). Symbolic interactionism: Perspective and method. Englewood Cliffs, NJ: Prentice-Hall, Inc.

Carr, W., \& Kemmis, S. (1986). Becoming critical: Education, knowledge and action research. Sussex: Falmer Press.

Coe, K., Carl, A., \& Frick, L. (2010). Lesson study in continuing professional teacher development: A South African case study. Acta Academica, 42(4), 206-230. Available from http://journals.sabinet.co.za/WebZ/images/ejour/academ/academ v42 n4_a8.pdf?sessionid=01-59893-1679460615\&format=F

Cohen, L., Manion, L., \& Morrison, K. (2005). Research methods in education. (5th edn.). London: Routledge Falmer.
Creswell, J.D. (2003). Research design: Qualitative, quantitative and mixed methods approaches. (2nd edn.). Thousand Oaks, CA: Sage Publications.

Day, C. (1999). Professional development and reflective practice: Purposes, processes and partnerships. Pedagogy, Culture \& Society, 7(2), 221-233. http://dx.doi. org/10.1080/14681369900200057

Dewey, J. (1933). How we think: A restatement of reflective thinking to the educative Process. Boston: Heath.

Farrell, T.S.C. (2004). Reflective practice in action. Thousand Oaks, CA: Corwin Press, Inc.

Fernandez, C., \& Yoshida, M. (2004). Lesson study: A Japanese approach to improving mathematics teaching and learning. Mahwah, NY: Lawrence Erlbaum.

Friedman, R.E. (2005). An examination of lesson study as a teaching tool in U.S. public schools. Unpublished doctoral dissertation. Ashland University, Ashland, $\mathrm{OH}$ United States. Available from http://etd.ohiolink.edu/send-pdf.cgi/Friedman\%20 Ruth\%20E.pdf?ashland1116871771

Hix, S.L. (2008). Learning in lesson study: A professional development model for middle school mathematics teachers. Unpublished doctoral dissertation. University of Georgia, Athens, GA, United States. Available from http://jwilson. coe.uga.edu/pers/hix sherry_I 200808 _phd.pdf

Jay, J.K., \& Johnson, K.L. (2002). Capturing complexity: A typology of reflective practice for teacher education. Teaching and Teacher Education, 18, 73-85. http://dx.doi. org/10.1016/S0742-051X(01)00051-8

Jita, L.C., Maree, J.G., \& Ndlalane, T.C. (2006). Lesson study (Jyugyo Kenkyu) from Japan to South Africa: A science and mathematics intervention program for secondary school teachers. In B. Atweh, A.C. Barton, M. Borba, N. Gough, C. Keitel, C. Vistro$\mathrm{Yu}$, et al. (Eds.), Internationalisation and globalisation in mathematics and science education (pp. 465-486). Dordrecht: Springer.

Lee, $\mathrm{H}$-J. (2005). Understanding and assessing preservice teachers' reflective thinking. Teaching and Techer Education, 21, 699-715.

Lee, W.H., \& Tan, S.K. (2004). Reflective practice in Malaysian teacher education Singapore: Marshall Cavendish Academic.

Lewis, C.C. (2000, April). Lesson study: The core of Japanese professional development. Paper presented at the Annual Meeting of the American Educational Research Association, New Orleans, LA. Available from http://www.lessonresearch.net/ aera2000.pdf

McKeny, T.S. (2006). A case-study analysis of the critical features within field experiences that affect the reflective development of preservice secondary mathematics teachers. Unpublished doctoral thesis. Ohio State University, Columbus, $\mathrm{OH}$, United States.

Mewborn, D.S. (1999). Reflective thinking among preservice elementary mathematics teachers. Journal for Research in Mathematics Education, 30, 316-341. http:// dx.doi.org/10.2307/749838

Meyer, R.D., \& Wilkerson, T.L. (2011). Lesson study: The impact on teachers' knowledge for teaching mathematics. In L.C. Hart, A. Alston, \& A. Murata (Eds.), Lesson study research and practice in mathematics education (pp. 15-26). Dordrecht: Springer. $\mathrm{http}: / / \mathrm{dx}$.doi.org/10.1007/978-90-481-9941-9_2

Murata, A. (2011). Introduction: Conceptual overview of lesson study. In L.C. Hart, A. Alston, \& A. Murata (Eds.), Lesson study research and practice in mathematics education (pp. 1-12). Dordrecht: Springer. http://dx.doi.org/10.1007/978-90481-9941-9_1

Nieuwenhuis, J. (2010). Qualitative research designs and data gathering techniques. In K. Maree (Ed.). First steps in research (pp. 69-97). Pretoria: Van Schaik Publishers.

Olsen, J.C., White, P., \& Sparrow, L. (2011). Influence of lesson study on teachers' mathematics pedagogy. In L.C. Hart, A. Alston, \& A. Murata (Eds.), Lesson study research and practice in mathematics education (pp. 39-57). Dordrecht: Springer http://dx.doi.org/10.1007/978-90-481-9941-9_4

Ottesen, E. (2007). Reflection in teacher education. Reflective Practice, 8(1), 31-46. http://dx.doi.org/10.1080/14623940601138899

Pedro, J.Y. (2001). Reflection in teacher education: Exploring preservice teachers' meanings of reflective practice. Unpublished doctoral dissertation. Virginia Polytechnic Institute and State University, Blacksburg, VA, United States.

Pollard, A. (2002). Reflective teaching: Effective and evidence-informed professional practice. London: Continuum.

Posthuma, A.B. (2011). The nature of mathematics teachers' reflective practice. Unpublished doctoral dissertation. University of Pretoria, Pretoria, South Africa. Available from http://upetd.up.ac.za/thesis/available/etd-04252012-164207/

Prus, R. (1996). Symbolic interaction and ethonographic research: Intersubjectivity and the study of human lived experience. New York, NY: State University of New York Press.

Rodgers, C. (2002). Defining reflection: Another look at John Dewey and reflective thinking. Teachers College Record, 104(4), 842-86. http://dx.doi. reflective thinking. Teachers
org/10.1111/1467-9620.00181

Schön, D.A. (1983). The reflective practitioner. San Francisco, CA: Jossey-Bass.

Setati, M., Adler, J., Reed, Y., \& Bapoo, A. (2002). Incomplete journeys: Code-switching and other language practices in Mathematics, Science and English language classrooms in South Africa. Language and Education, 16, 128-149. http://dx.doi. org/10.1080/09500780208666824

Sowder, J.T. (2007). The mathematical education and development of teachers. In F.K. Lester (Ed.), Second handbook of research on mathematics teaching and learning (pp. 157-223). Charlotte, NC: Information Age. 
Sparks-Langer, G., \& Colton, A. (1991). Synthesis of research on teachers' reflective thinking. Educational Leadership, 48(6), 37-44.

Takahashi, A., Watanabe, T., \& Yoshida, M. (2006). Developing good mathematics teaching practice through lesson study: A U.S. perspective. Tsukuba Journal of Educational Study in Mathematics, 25, 197-204. Available from http://www. human.tsukuba.ac.jp/ mathedu/2516.pdf

Taylor, A.R., Anderson, S., Meyer, K., Wagner, M.K., \& West, C. (2005). Lesson study: A professional development model for mathematics reform. The Rural Educator, Winter 2005, 17-22. Available from http://www.ruraleducator.net/ archive/26-2/26-2_Taylor.pdf

Valli, L. (1992). Reflective teacher education: Cases and critiques. Albany, NY: State University of New York Press.

Valli, L. (1997). Listening to other voices: A description of teacher reflection in the United States. Peabody Journal of Education, 72(1), 67-88. http://dx.doi. org/10.1207/s15327930pje7201_4

Van Manen, M. (1977). Linking ways of knowing with ways of being practical. Curriculum Inquiry, 6, 205-228. http://dx.doi.org/10.2307/1179579
Ward, J.R., \& McCotter, S.S. (2004). Reflection as a visible outcome for preservice teachers. Teaching and Teacher Education, 20(3), 243-257.

Warfield, J., Wood, T., \& Lehman, J.D. (2005). Autonomy, beliefs and the learning of elementary mathematics teachers. Teaching and Teacher Education, 21, 439-456. http://dx.doi.org/10.1016/j.tate.2005.01.011

York-Barr, J., Sommers, W.A., Ghere, G.S., \& Montie, J. (2006). Reflective practice to improve schools. Thousand Oaks, CA: Corwin Press.

Zeichner, K.M., \& Liston, D.P. (1996). Reflective teaching: An introduction. Mahwah, NJ: Lawrence Erlbaum Associates, Inc.

Zeichner, K., \& Tabachnick, B.R. (1991). Reflections on reflective thinking. In B.R Tabachnick, \& K. Zeichner (Eds.), Issues and practices in inquiry-oriented teacher education (pp. 1-21). London: Falmer Press.

Zwodiak-Myers, P. (2009). An analysis of the concept reflective practice and an investigation into the development of student teachers' reflective practice within the context of action research. Unpublished doctoral dissertation. Brunel University, Middlesex, United Kingdom. 